\title{
Twenty-five years of adaptation finance through a climate justice lens
}

\section{Mizan Khan ${ }^{1} \cdot$ Stacy-ann Robinson ${ }^{2}$ (D) $\cdot$ Romain Weikmans $^{3}$ (D) David Ciplet $^{4}$. J. Timmons Roberts ${ }^{5}$}

Received: 3 February 2019 / Accepted: 11 September 2019 / Published online: 29 October 2019

C The Author(s) 2019, corrected publication 2019

\begin{abstract}
How much finance should be provided to support climate change adaptation and by whom? How should it be allocated, and on what basis? Over the years, various actors have expressed different normative expectations on climate finance. Which of these expectations are being met and which are not; why, and with what consequences? Have new norms and rules emerged, which remain contested? This article takes stock of the first 25+ years of adaptation finance under the United Nations Framework Convention on Climate Change (UNFCCC) and seeks to understand whether adaptation finance has become more justly governed and delivered over the past quarter century. We distinguish among three "eras" of adaptation finance: (1) the early years under the UNFCCC (19922008); (2) the Copenhagen shift (2009-2015); and (3) the post-Paris era (2016-2018). For each era, we systematically review the justice issues raised by evolving expectations and rules over the provision, distribution, and governance of adaptation finance. We conclude by outlining future perspectives for adaptation finance and their implications for climate justice.
\end{abstract}

Keywords Adaptation finance $\cdot$ Climate justice $\cdot$ United Nations Framework Convention on Climate Change (UNFCCC)

\section{Introduction}

It is about power politics, and the rich and the powerful never, ever voluntarily give up their power and their wealth. And so it has to be extracted like teeth in a dentist chair. Saleemul Huq, Director of the International Centre for Climate Change and Development (ICCCAD), Dhaka, 2014.

The original version of this article was revised. Unfortunately the uncorrected version of the article was published online. This has been corrected.

This article is part of a Special Issue, "Climate Finance Justice: International Perspectives on Climate Policy, Social Justice, and Capital," edited by Lauren Gifford and Chris Knudson

Stacy-ann Robinson

stacy-ann.robinson@colby.edu

Extended author information available on the last page of the article 
These words of Saleemul Huq, from a Guardian newspaper podcast, reflect his lifetime of experience of the intense power struggles over international climate adaptation finance. These struggles have involved conflicts related to several key questions: How much finance should be provided to support climate adaptation? Who should provide adaptation finance? Through which channels should adaptation finance be delivered to developing countries? How should it be allocated? Should some countries be prioritized? Which, and on what basis? Does adaptation finance represent a form of compensation from "polluting" countries to "victims" of climate change? Such questions on the norms and rules that guide adaptation finance are at the core of climate justice. Over the years, various actors have expressed different normative expectations about adaptation finance. Which of these expectations are being met and which are not; why, and with what consequences? Have new norms and rules emerged, which remain contested?

This article takes stock of the first 25+ years of adaptation finance under the United Nations Framework Convention on Climate Change (UNFCCC or "the Convention") and seeks to understand whether adaptation finance has become more justly governed and delivered over this past quarter century. Following Grasso (2010, p. 53), we define adaptation finance justice as a "[...] fair process, that involves all relevant Parties, of raising adaptation funds according to the responsibility for climate impacts, and of allocating raised funds putting the most vulnerable first." In doing so, we distinguish among three "eras": (1) the early years of adaptation finance under the UNFCCC (1992-2008), (2) the Copenhagen shift (2009-2015), and (3) the post-Paris era (2016-2018). For each era, we systematically review the justice issues raised by evolving expectations and rules over the provision, distribution, and governance of adaptation finance. Based on our observation of multiple UNFCCC negotiations and on interviews with negotiators and observers, we also analyze whether these expectations and rules are reflected in the actual, behaviors of actors and reflect on the impacts of potential disconnections between expectations, rules, and behaviors on climate justice. We conclude by outlining future perspectives for adaptation finance in the contemporary period of neoliberal climate governance.

\section{Climate justice as it relates to climate finance}

There are several types of justice-distributive, procedural, recognition, compensatory, restitutive, corrective, or neoliberal justice (e.g., see Ciplet and Roberts 2017; Fraser 1998; Ikeme 2003; Klinsky and Dowlatabadi 2009; Rawls 1971; Young 1990). The concept of distributive justice refers to a situation where all primary social goods, e.g., opportunity, income, and wealth, are distributed equally unless an unequal distribution of any or all of these goods is to the advantage of the least favored, which guarantees a fair deal for the most disadvantaged (Rawls 1971). Equity and fairness are key concepts of distributive justice.

Distributive justice, however, usually cannot be ensured without investigating the structural elements that cause injustices, e.g., social structures, power relations, and institutional contexts, which may cause oppression and domination (Young 1990). Therefore, procedural justice refers to the representation of all who have a stake in the outcomes of decision-making processes (Klinsky and Dowlatabadi 2009). "Recognition" is another distinct concept concerned with "making visible histories of discrimination and disrespect" (Hobson 2003, p. 5) and challenging the norms, values, and meanings that legitimize inequality (Fraser and Honneth 2004, p. 29). Distributive and procedural justice and recognition are interdependent; they consider the resources that should be redistributed, to whom, and the norms guiding decision-making processes. With compensatory, restitutive and corrective justice, people's rights are to be 
respected, not violated or harmed through others' actions; if not done, compensation must be paid to those harmed. Compensatory justice calls for providing the equivalent of that which the harm has caused (Goodin 1989). In practice, there are other ways to provide compensation; however, what constitutes a just approach is subjective (see Goodin 1989).

Despite repeated calls from developing countries and civil society actors for distributive, procedural, and compensatory justice for harm caused, wealthy countries have avoided measures that would evoke responsibility and incur liability. Neoliberal justice, which promotes libertarian principles of "justice as mutual advantage" and "justice as private property," has often been favored by wealthy countries, and has been reflected in more recent UNFCCC texts (see Ciplet and Roberts 2017). Justice as mutual advantage speaks to "rational agreement of agents to cooperate with one another to further their self-interest" (cited in Ciplet and Roberts 2017, p. 150). As private property, it emphasizes the importance of property rights over all others. Institutions, it is argued, should protect the freedom of actors to exploit their natural advantages. Together, these principles allow for culpable Parties to avoid legal liability and for the framing of climate adaptation finance provision as goodwill or subject to market forces, rather than preconditions for establishing responsibility for creating the problem in the first place.

As it relates to climate adaptation, justice should be contextualized within the normative, institutional, and political realities of the process from which concerns have emerged (Ciplet et al. 2013). Shue (1992, p. 386) argues that questions of justice are not external to international climate negotiations on three grounds: (1) "background injustice" is not lost sight of by the Parties involved in the negotiations, which, over time, give rise to what others call "principled beliefs"; (2) the harm caused by the rich nations, though done unintentionally, is the subject of negotiation and cooperation; and (3) avoiding the issue of justice would ultimately condemn the poor nations to sacrificing their "vital" interests, namely survival, in order for the rich nations to avoid sacrificing their "trivial" interests (also see Roberts and Parks 2006; Vanderheiden 2011, p. 65).

Considering this context of governance and the numerous conceptions of justice, this article raises the following queries, as it relates to adaptation finance: Who should provide adaptation finance, how much, and to whom? On what basis and through what mechanisms should it be delivered? How should those mechanisms be governed? In the next three sections, we identify three "eras" of adaptation finance and review the evolution of climate regime provisions and actual behaviors of actors according to these guiding justice issues. In our conclusion, we argue that emerging neoliberal characteristics and the guiding principles of the contemporary climate regime present distinct challenges to advancing justice related to adaptation finance.

\section{The early years of adaptation finance under the UNFCCC (1992-2008)}

\subsection{The emergence of the climate debt frame}

The concepts of carbon debt, climate debt, and ecological debt were introduced into international climate politics in the late 1990s by non-governmental organizations (NGOs) such as Acción Ecológica and Christian Aid (see Roberts and Parks 2006; Simms et al. 1999). The specific networks that pushed for gains in this area were broad-based, loosely tied, and often involved developing country State and non-State actors in the Global South and North working in tandem. Climate debt advocates purport that the Global North owes the Global South a climate debt, which is far greater than the Third World financial debt due to its 
disproportionate use of atmospheric space without payment (Martinez-Alier 2002). The concept evolved to have two main components. First, because wealthy countries have utilized most of the atmospheric space for storing carbon emissions, developing countries should be paid an "emissions debt" to account for their fair share of atmospheric space. Second, wealthy countries owe an "adaptation debt" which represents compensation owed to enable developing countries to adapt and respond to climate impacts that are not of their own making (see Government of Bolivia 2009b).

Around the same time, States in the Global South began expressing demands in this area. This message was galvanized in the statement released by the Heads of State and Government at the Group of 77 (G77) and China's South Summit in Havana in 2000 (see G77 and China 2000, online). In subsequent years, the least developed countries (LDCs), Alliance of Small Island States (AOSIS), G77, and a coalition of more than 30 Western NGOs, policy institutes, and think tanks began to aggressively push for remuneration of the ecological and climate debts (Roberts and Parks 2009), in addition to calling for wealthy States to take the lead on cutting emissions. While this was a core demand of the LDCs since their founding as a negotiating group in 2002 and a full decade earlier by AOSIS, adaptation was still not widely viewed as a core issue in the negotiations.

The concept of climate debt is closely associated with the emergence of the global climate justice movement. The Eighth Conference of the Parties (COP) to the UNFCCC in New Delhi in 2002 signaled the emergence of the climate justice movement: a coalition of fishers from the Indian States of Kerala and West Bengal representing the National Fishworkers' Forum, farmers from the Agricultural Workers and Marginal Farmers Union, and a delegation of Indigenous peoples from the mining-impacted areas of Orissa and threatened by the massive Narmada Dam marched in the streets. Delegates of NGOs from 20 other countries also participated in the march (Khastagir 2002). In the same year, an international coalition of groups gathered in Johannesburg for the World Summit on Sustainable Development and released a formative statement for the climate justice movement called the "Bali Principles of Climate Justice." Ecological debt was a key tenet of this document. For example, it called for, "Affirming the principle of ecological debt, climate justice protects the rights of victims of climate change and associated injustices to receive full compensation, restoration, and reparation for loss of land, livelihood, and other damages" (CorpWatch 2002, online).

It was not until COP13 in Bali in 2007 that developing countries made adaptation a core demand at the negotiations. Arguing that adaptation in the UNFCCC documents and discussions was "piecemeal," Tuvalu, on behalf of the LDCs and AOSIS, introduced the so-called International Blueprint on Adaptation (see Government of Tuvalu 2007). This document would largely set the agenda on adaptation politics for the next five years (though crucial elements were watered down). In addition to calling for predictable and adequate funding and a coordinated international response to adaptation, the blueprint introduced a novel demand for a "burden sharing mechanism." This included a proposal for an international levy on international aviation and maritime transport to fund adaptation in vulnerable countries.

\subsection{UNFCCC provisions on adaptation/adaptation finance}

During the first decade and a half of negotiations, the concept of justice was not explicitly defined in the UNFCCC. However, other provisions in the Convention implied the meaning of justice (Okereke 2008). For example, Paragraph 3 of the Convention's Preamble refers to disproportionate "per capita" and "historical emissions" of developed countries. The 
Convention's basic principles also guide the global community on addressing climate change, particularly the cardinal principle of "common but differentiated responsibilities and respective capabilities" (CBDR+RC). In view of developed countries having the largest share of historical and present-day emissions, they were to lead on mitigating greenhouse gas emissions (Article 3.1) and on supporting adaptation in vulnerable countries (Article 4.4), including providing financial assistance with "new and additional" monies (Article 4.3). The CBDR+RC principle also implicitly refers to the polluter pays principle (i.e., those who produce pollution should bear the costs of managing it so as to prevent damage to the environment or human health). The provisions of the Convention such as Article 4.3 and Article 4.4, which highlight "the need for adequacy and predictability in the flow of funds and the importance of appropriate burden sharing among the developed country Parties" and which calls on Annex II Parties [developed country Member States of the Organisation for Economic Co-operation and Development (OECD)] to "assist the developing country Parties that are particularly vulnerable to the adverse effects of climate change in meeting costs of adaptation," respectively, are a clear recognition and acceptance of developed country responsibilities. Further, special consideration is directed to the needs and concerns of specific categories of developing countries and LDCs through the provision of finance, technology, and insurance mechanisms (Articles 4.8 and 4.9). These provisions indicate an implied acceptance that the Annex II Parties should provide compensation to the developing countries, as subject to availability (Article 11 para. 3(d)).

Having been drafted in 1991 and 1992, however, the Convention focused mostly on mitigation as the ultimate solution to climate change, though there are five references to adaptation. In the initial years, adaptation was overlooked in part because of the apprehension that it might lead Parties to underemphasize mitigation (Ciplet et al. 2015). Moreover, while AOSIS raised the issue of compensation for climate impacts suffered, compensatory justice was largely neglected by the COP, and relegated to a decision on the provision of insurance (see Article 4.8) (Khan 2014). This was, in part, due to the fact that the climate regime has often narrowly reflected market-based solutions of both economic growth and climate change within the framework of neoliberal, market economics (Ciplet and Roberts 2017). This placed adaptation on the back burner in terms of the developed countries taking responsibility for climate change.

On the one hand, with the publication of the Third and Fourth Assessment Reports of the Intergovernmental Panel on Climate Change (IPCC) in 2001 and 2007, respectively, climate change issues began to be seen as development issues that required the mainstreaming of adaptation. On the other hand, mitigation was not being taken seriously by the developed countries. As a result, COP7 adopted the Marrakesh Accords in 2001, which, among other things, contained the first substantial package on adaptation. There, three Funds were established - the Least Developed Countries Fund (LDCF) and the Special Climate Change Fund (SCCF) under the Convention and the Adaptation Fund under its 1997 Kyoto Protocol (Decisions 5/CP.7, 6/CP.7 and 10/CP.7).

In terms of adaptation finance, this period witnessed the laying out of infrastructures and the operationalization of the newly established Funds under the UNFCCC regime. The Global Environment Facility (GEF), since its inception in 1993, began to fund adaptation projects. But developing countries were skeptical of the Facility because it is donor-controlled, based at the World Bank in Washington, D.C., and requires that all spending result in global public goods benefits, including in the case of adaptation projects (Khan 2014; Khan and Roberts 2013). Gradually, this policy was relaxed, and the Facility began accommodating a broader approach to adaptation funding. 


\subsection{Who should get adaptation finance?}

In terms of distributive justice, there were numerous provisions on burden sharing among industrialized countries (Decision 10/CP7; Articles 4.3 and 11.2 of the Convention and Kyoto Protocol, respectively). The Convention obligates that Annex I [or developed] countries "shall" "meet the costs of adaptation" in particularly vulnerable countries (Article 4.4). Moreover, it implies a commitment to distributive justice where particularly vulnerable countries should be prioritized (Decision 5/CMP2; Decision 1/CMP3). The Convention, however, never defined the term "particularly vulnerable." For setting a list of criteria of vulnerability, an assessment process was approved in 1995, with the first decision on guidance for financial mechanisms. Although there is a broad understanding of the need for the prioritization of eligible countries based on vulnerability, the G77, the largest negotiating bloc of developing countries, never pursued this issue further because of political sensitivities. At COP13 in Bali in 2007, the Bali Action Plan was adopted, which put adaptation as one of the four pillars, together with mitigation, technology transfer, and finance. The Adaptation Fund was operationalized, with the GEF working as the Trustee, which it also did for the other two Funds - the LDCF and the SCCF. African countries were subsequently included in the Bali Action Plan alongside the LDCs and the small island developing States (SIDS) by virtue of also being "particularly vulnerable to the adverse effects of climate change" (para. 1(c)(i)).

But there remained the issue that funds may not be allocated in a way that prioritized the most vulnerable groups; instead, some funding allocation formulae reflected donor interests more than the needs of vulnerable countries; others distributed funds by a quota system with flat amounts across groups of nations (Ciplet et al. 2013). This puzzle raised the question: how can "fair" funding allocation criteria be developed without disrupting developing country solidarity? As Jagers and Duus-Otterström (2008, p. 577) argue, adaptation poses distributive justice-related questions that are "not only between burden-takers (i.e., those who take adaptive or mitigating action) but also between recipients of benefits." Some of the associated ethical issues have been directly addressed in the literature, for example, through the definition of burden sharing rules for allocating the cost of adaptation (e.g., see Baer et al. 2009; Dellink et al. 2009; Jagers and Duus-Otterström 2008), or indirectly through the individuation of responsibility for climate cost burdens (e.g., see Caney 2005; Paavola and Adger 2006; Page 2008).

\subsection{Procedural justice-governance of financial mechanisms}

Grasso (2010, p. 53) argues that both procedural and distributive justice in adaptation financing can be ensured through a "fair process which involves all relevant Parties, of raising adaptation funds according to responsibility for climate impacts, and of allocating the funds raised in a manner that puts the most vulnerable first." Accordingly, there have been major struggles over who should oversee climate Funds and how the Funds should be structured. Developing countries and civil society groups, often critiquing international aid practices as extending the neo-colonial interests of wealthy countries, pushed for the COP to oversee the Funds with "equitable and balanced representation" (Articles 11 and 11.2). Notably, the guiding principles of the Adaptation Fund include "access to the Fund in a balanced and equitable manner" (Decision 5/CMP.2 para. 1(b)) and "transparency and openness in the governance of the Fund" (para. 1(c)). The governing body is also to be constituted by Parties in the Kyoto Protocol, based on the one country-one vote rule, which should ensure strong 
representation by developing countries (para. 5 and 6); projects financed through the Adaptation Fund are to be "country driven" and "based on needs, views, and priorities of eligible parties [...]" (Decision 5/CMP.2 para. 2(c)).

Developed countries preferred that the GEF oversee the Funds. Since major donors have near veto power at the World Bank, where the Facility is based, developing countries objected to the GEF having administrative power over UN Funds. Further controversy was added by the GEF's earlier Resource Allocation Framework, which was based on two criteria - global benefits from projects and country performance (GEF 2010). The criterion of "global benefits" is seen by the LDCs as a way of diverting most of the GEF resources to mitigation, while leaving almost nothing for adaptation. Despite developing country opposition, the LDCF and SCCF continue to be administered by the GEF (Decision 1/CMP.4).

\section{The shift in Copenhagen (2009-2015)}

\subsection{Adaptation finance justice demands}

The Climate Action Network (CAN) International, Climate Justice Now!, a new climate justice network, and other civil society networks such as the Pan African Climate Justice Network, representing 63 NGOs from across Africa, attended COP15 in Copenhagen in record numbers in 2009. Many of these groups had adopted a justice message at the negotiations, focused on realizing a legally binding and enforceable treaty, and for wealthy countries to pay their climate debt, including the establishment of a Fund under the COP to administer such finance.

Civil society groups in both CAN International and the newly formed Climate Justice Now! network made calls during this period for innovative public finance mechanisms to fund adaptation. CAN International, while focusing most of its attention on mitigation, called for adaptation to have equal footing with mitigation in the Convention (e.g., see CAN International 2007). Many of the more radical groups demanded a "solidarity fund" or a "reparations fund" to administer climate debt to countries of the South. A sign-on letter was issued earlier in 2009 before the intersessional in Bonn by the Third World Network in order to "galvanize the members of the civil society and social movements globally to support the call for the repayment of the climate debt and to advance these calls in the climate negotiations" (cited in Raman and Lin 2009, online).

In Copenhagen, other civil society networks also called for repaying the climate debt and for displacing a growing focus on market mechanisms in favor of public support (developed country government-funded adaptation pledges and payments to developing countries). These included a statement by participants of the Indigenous Peoples' Global Summit on Climate Change held in Anchorage, Alaska, which was agreed by Indigenous representatives from the Arctic, North America, Asia, the Pacific, Latin America, Africa, the Caribbean, and Russia (see Inuit Circumpolar Council 2009), a statement by the Pan African Climate Justice Alliance, and a statement by the Trade Union Conference of the Americas, including people from across Latin America and the Caribbean (Third World Network 2009). The movement to get wealthy countries to pay their climate debt was gaining momentum, and upon entering the Bella Center in Copenhagen, it was hard to miss this message which decorated countless signs in the NGO display booths and buttons on backpacks and 
jackets of civil society members. For example, the Pan African Climate Justice Alliance declared:

"For their disproportionate contribution to the effects of climate change-causing rising costs and damage in our countries that must now adapt to climate change - the developed countries have run up an "adaptation debt." Together the sum of these debts - emissions debt and adaptation debt — constitutes the climate debt. Proposals by developed countries in the climate negotiations, on both mitigation and adaptation, are inadequate. They seek to pass on the costs of adaptation and mitigation, avoiding their responsibility to finance climate change response efforts in Africa" (Pan African Climate Justice Alliance 2009, online).

This statement sought to stand in support of States in the negotiations that made similar official statements on climate debt in the UNFCCC process, including a Declaration by Bolivia, Cuba, Dominica, Honduras, Nicaragua, and Venezuela, a speech by the Sri Lankan Environment Minister, and a statement by the Lesotho delegate on behalf of the LDC negotiating group (Third World Network 2010). For example, the Latin American countries above declared that:

As for climate change, developed countries are in an environmental debt to the world because they are responsible for $70 \%$ of historical carbon emissions into the atmosphere since 1750. Developed countries should pay off their debt to humankind and the planet; they should provide significant resources to a fund so that developing countries can embark upon a growth model which does not repeat the serious impacts of the capitalist industrialization (cited in Rabble News 2009, online).

Likewise, the Sri Lankan Environment Minister explained: "If we adopt [the] scientific criteria of [the] IPCC, these so-called developed countries should cut their emission level by at least $70-90 \%$ by 2020 . On the other hand, they owe environmental debt to other countries and should compensate them by establishing an adaptation fund" (cited in Nizam 2009, online).

Low-income States including the LDCs, AOSIS Members, and Bolivia came into the pivotal negotiations in Copenhagen with other ambitious demands. These included a legally binding treaty that would keep average global temperature rise below $1.5^{\circ} \mathrm{C}$, US $\$ 400$ billion of "faststart finance" from wealthy countries to enable those hardest hit by climate change to adapt to its impacts, and an equitable share of the atmosphere to ensure adequate "development rights" (see AOSIS 2009; Government of Bolivia 2009a; Ourbak and Magnan 2017). Tuvalu's blueprint, which it had tabled at COP13 in Bali in 2007, called for an International Climate Insurance Pool that included internationally-agreed threshold triggers such as wind speed, flood levels, sealevel rise, drought indices, and inundation levels due to storm surge for payouts to communities. This would largely be a precursor to demands beginning in 2010 for a loss and damage mechanism $^{1}$.

The leadership and capacity of the LDCs grew stronger over the years. ${ }^{2}$ This, combined with the adept legal skills and ambitious demands of AOSIS, meant that the presence of the

\footnotetext{
${ }^{1}$ It is likely that the term "loss and damage" originated from this document. Page 15 reads "A template for assessing damage, losses, and needs after a disaster could be drafted to ensure rapid compensation for those affected."

${ }^{2}$ The LDCs have grown more forceful and organized, and there was over a decade of support from the European Capacity Building Initiative, directed by the Oxford Institute of Energy Policy, for developing its demands. This support included one- to two-week workshops on climate science, policy, and strategy development for LDC representatives.
} 
low-income States in the negotiations had become highly visible since the pivotal conference in Bali in 2007. On the eve of the negotiations in Copenhagen in 2009, the G77, despite major shifts in broader geopolitical relations, seemed as strong and capable as ever in challenging the interests of the Global North.

A central focus of the more radical civil society groups was pushing the World Bank and other major multilateral banks to get out of climate finance, something that was backed by numerous developing countries. To this end, during the first week of negotiations in Copenhagen, a mobilization took place outside the Bella Center calling for reparations and addressing the climate debt. Bolivian Ambassador to the UN, Pablo Solon-Romero, speaking at the Bolivia and Jubilee South Press Conference on December 14, joined in this call saying, "The first element we are speaking about is a debt of emissions, second we are speaking about a debt in adaptation, and third we are speaking about a debt to mother earth" (pers comm).

Other organizations, as part of the more moderate Climate Action Network, also took strong positions on climate finance for developing countries, a notable shift from the level of attention that they gave the issue just two years prior in Bali. These calls echoed the climate finance demands of low-income countries, and in some cases, sought to preempt what they saw as strategies of co-option for a weak political agreement on mitigation that were yet to come.

\subsection{Provision of adaptation finance}

The Copenhagen negotiations, dubbed by critics as "Brokenhagen," were a turning point in global climate politics. Expectations were high for a new agreement on climate action and support that finally addressed the injustices. Even after almost two decades, there were wide differences among groups of countries in the negotiations about how climate finance should be mobilized (Ciplet et al. 2015). There was a yawning gap in the amount of adaptation funds available to developing nations, compared with any assessment of adaptation needs. The Copenhagen Accord and the 2010 Cancun Agreements promised developing countries US $\$ 30$ billion in short-term "fast-start finance" for the period 2010 to 2012 and a "scaling up" to US\$100 billion per year by 2020 . However, the true meaning of these numbers depended on the interpretation of key phrases in the text, many of which were loosely defined or not defined at all (Roberts and Weikmans 2017). In our interviews with delegates from different blocs during these negotiations, widely different interpretations were derived.

First, the texts promised "adequate funding" yet developed countries fell short in this area. Donor countries did not make it clear how they would determine their financial contributions for adaptation. In order to know if the pledges and delivered funds are truly adequate, "we would need updated and best-knowledge estimates of need for mitigation and adaptation funding" (Ciplet et al. 2013, p. 58). Such estimates are very difficult to establish but the UN Environment Programme estimated that adaptation costs could range from US\$140 billion to US $\$ 300$ billion per year by 2030 , and between US $\$ 280$ billion and US $\$ 500$ billion per year by 2050 (UNEP 2016). The mobilization of US\$100 billion a year both for mitigation and adaptation by 2020 was clearly not in line with these cost estimates.

The proportion of the funding that would be in the form of pure grants, partial grants, or purely market rate loans was also not made clear. The Copenhagen Accord states that, "This funding will come from a wide variety of sources, public and private, bilateral, and multilateral, including alternative sources of finance." Despite repeated complaints about this mixing of two very different types of finance, during this period, there was no improved clarity 
regarding the proportion of funding that should or must be publicly raised in the agreements that followed, i.e., the Cancun Agreements of 2010, the Durban Platform of 2011, or the Doha or Warsaw Agreements of 2012 and 2013, respectively. The 2015 Paris Agreement avoids mentioning specifics, indicating that funds will be mobilized "from a wide variety of sources, instruments, and channels, noting the significant role of public funds [...]" (Article 9.3). But contributor nations are protecting their right to channel climate finance through their own bilateral agencies (and not just through the multilateral climate Funds established under the UNFCCC) and to provide loans and export credits, instead of grants-based assistance. While the United States (USA) allocated no money to the UNFCCC or the Green Climate Fund (GCF) in its Appropriations Bill for the 2018 Financial Year, for example, it has been channeling a larger amount of its climate finance support through its State Department, its Agency for International Development, and its Treasury (Thwaites 2018; United States Government 2018). This preference for prioritizing bilateral transfers is in no way surprising - the Paris Agreement avoids directly referencing some of the key principles of climate finance relating to funds mobilization, administration, governance, disbursement, and implementation (Schalatek and Bird 2015). And unlike the Convention, the Copenhagen Accord and the Cancun Agreements, the Paris Agreement also does not mention "alternative/innovative" sources of finance, such as funds that could be generated through a tax on international financial transactions or international air travel. These funds are critical for scaling up commitments from developed countries such as the USA.

The Copenhagen and Cancun texts as well as the Paris Agreement promise "predictable" funds, which is essential for developing countries to establish their own budgets and to plan for adaptation responsibly, but predictability did not increase in this period. Some quite developed proposals were put forward to levy international air passengers a small flat fee or to finally tax bunker fuels used in international shipping, instituting a tiny international transaction tax, or a tax on carbon, or even a tax on arms trade (see Gewirtzman et al. 2018; Richards and Boom 2014). However, none of these proposals were advanced and climate finance remained voluntary, depending most apparently on political expediency in the wealthy countries (Khan 2015).

Another issue impacting the predictability of funding during this period was the extreme fragmentation of climate finance (see Caravani et al. 2012). There were almost 100 dedicated funding channels, both bilateral and multilateral, with private foundations also actively mobilizing funds (OECD 2015). With so many funding channels, and sometimes little transparency regarding what is being funded, it was difficult for both contributors and recipients to adequately assess where money was going (Roberts and Weikmans 2017; Weikmans and Roberts 2019).

The phrase "scaled up" is another aspect that was not adequately addressed during this era. After years of the wealthy nations putting only token amounts of voluntary funding into the UN climate Funds, developing nations pushed for real, "scaled up" funding after Copenhagen. This phrase came to stand for the post- "fast-start finance" period, from 2013 to 2020, when the Cancun Agreements specified a tenfold "scale up" of funding per year. Yet, there was no language in the associated UNFCCC decisions indicating a plan for the "scaling up" period. In 2013, only US\$25 billion (7\% of total flows) of public funds supported adaptation, despite previous agreements on maintaining a balance between funding adaptation and mitigation (Buchner et al. 2014; Ciplet et al. 2013). More recent years have seen small improvements in the imbalance (Carty and Comte 2018). Also disquieting is that the overwhelming share of climate finance (76-80\%) is actually official development assistance, defined as "government aid that promotes and specifically targets the economic development and welfare of developing countries" (OECD 2018b, p. 1). This suggests that climate funds are not additional to what would have been delivered anyway 
(Nakhooda et al. 2013). In the Paris talks in 2015, the OECD published a report claiming that developed countries provided US\$62 billion in climate finance in 2014 (OECD and CPI, 2015). The Indian delegation, based on their analysis, responded that only US $\$ 2.2$ billion could be regarded as credible new and additional climate support (Government of India 2015).

Overall, the above issues suggest that while low-income States succeeded in some ways in their efforts during this period to have adaptation finance scaled up, large gaps in justice remained. Never were fair shares or carbon debt-based approaches seriously considered in the formal negotiations. Moreover, it seemed unlikely that the emerging "loss and damage" agenda, focused on those climate impacts that cannot be readily adapted to, would result in a rebalancing of this power dynamic.

\subsection{Who should get adaptation finance?}

During this second era, there was no formalization of which countries should be prioritized for receiving adaptation funding. Though the Copenhagen Accord, and the Cancun and Paris Agreements recognize that preference should be given to the particularly vulnerable countries, the Paris Agreement avoids mentioning those countries in Africa as part of the particularly vulnerable countries group. The Copenhagen Accord had the expression of "the most vulnerable countries." The Africa Group, led by Egypt and South Africa, was very active in the negotiations and continues to lobby for such recognition. Some other developing countries also floated the idea of "highly vulnerable countries." This effort has been referred to as something of a "beauty contest" to identify those countries that are the most vulnerable (CAN International, 2010, online). While the proposal for "highly vulnerable countries" was rejected by the G77, it indicates the perceived benefits that gaining specific vulnerability status might have for certain poor and vulnerable countries in the UNFCCC. This process also indicates the risk that concessions based on special status can have on disrupting solidarity among developing countries (Ciplet et al. 2013). However, after Copenhagen, disunity among the G77 intensified (Khan et al. 2013). Some activists from the Global South even called for the dismantling of the bloc (Narain et al. 2011).

Studies on the distribution of adaptation finance did not concretely establish that money was directed to the most vulnerable countries (Betzold and Weiler 2017 is an exception). In the case of SIDS, for example, more adaptation finance went to countries with good governance quality and low per capita incomes (Robinson 2018a, 2018b; Robinson and Dornan 2017). The Maldives, which ranked first of all SIDS on an average of the University of Notre Dame's Global Adaptation Index for exposure between 2010 and 2014, received the 18th largest commitment of approximately US\$23 million (Robinson and Dornan 2017). These studies should, however, be considered with caution, given the poor quality of adaptation finance data (e.g., see Kono and Montinola 2019; Weikmans et al. 2017), and the lack of reliable vulnerability indicators (e.g., see Füssel 2010; Klein 2009).

\subsection{Governance of climate finance/procedural issues}

During this era, the World Bank continued to serve as the Trustee of the LDCF and SCCF, while the Adaptation Fund was administered by a 16-member board, with 10 representatives from developing countries, and the remaining six from developed countries. The newly established GCF was operationalized and administered by a 24-member board, with equal representation from the developed and developing world. At COP18 in Doha in 2012, however, some developed countries unsuccessfully made efforts to dilute the accountability 
of the GCF to the COP, and thus weaken developing country decision-making over the Fund (Article 11.1 of the Convention plus Decision 3/COP17). Also, a 20-member Standing Committee on Finance with equal representation from developed and developing countries was operationalized to oversee the coordination, rationalization, mobilization, and the measurement, reporting, and verification of finance. As the financial architecture of the climate regime remained extremely fragmented, this high-level committee, with direct accountability to the COP, was tasked with rationalizing and making the whole process of raising and distributing climate finance more coherent. The committee was, however, given no power to force nations to behave differently-instead, it assumes the role of assessor of the Biennial Reports submitted by developed countries every two years.

In terms of concretizing compensatory justice, not much progress was made during this era. While the Paris Agreement recognizes the importance of "averting, minimizing, and addressing loss and damage associated with the adverse effects of climate change" (Article 8), it avoids tackling the dual issue of liability and compensation by explicitly stating that the Article "does not involve or provide a basis for any liability or compensation." Key Parties such as the USA opposed arguments for liability and compensation (Vanhala and Hestbaek 2016). As a result, the Article promotes sustainable development as a way of reducing the risk of loss and damage, which does not provide a concrete pathway for particularly vulnerable countries to be financially compensated.

\section{The post-Paris era (2015-2018)}

\subsection{Adaptation finance justice demands}

Both civil society and developing countries came into the Paris negotiations with many similar demands: a dramatic scaling up of public finance through innovative strategies, the paying of climate debt, a robust mechanism to address loss and damage, and equitable governance structures. Much attention was directed toward scaling up finance commitments to support initiatives outlined by developing countries as part of their new "Nationally Determined Contributions" plans. Moreover, many called on wealthy States to meet their Copenhagen commitments for the annual US $\$ 100$ billion mobilization goal to equally target mitigation and adaptation, and for up-scaled post-2020 commitments commensurate with the escalating needs on the ground. Many criticized a growing focus on private finance in institutions such as the GCF in lieu of public funds and governance forms that reflected business as usual, rather than the "transformative" approach outlined in the Fund's mission statement. Civil society groups such as Jubilee South and Oxfam also critiqued the ways in which climate finance was further indebting LDCs such as Mozambique and causing increased dependency when primarily provided as loans as opposed to grants.

\subsection{Provision of adaptation finance}

The preamble of the Paris Agreement notes the importance of the concept of "climate justice" with respect to climate action. The principle of equity and $\mathrm{CBDR}+\mathrm{RC}$ was revised, and the words "in the light of different national circumstances" added to the preamble. This is a weakening of the cardinal principle as the justice elements were restricted to the non-binding section of the Agreement.

The Paris Agreement reiterates the obligation for developed countries to provide climate finance to developing countries for mitigation and adaptation, while developing countries may 
voluntarily contribute to financing efforts (Article 9.2). It pushed the annual goal of US\$100 billion forward, to be sustained from 2020 to 2025, prior to which a new target will be agreed. Though it stipulates a global goal on adaptation, recognizing the international dimension of adaptation, the pronouncements remained vague, but one positive aspect of the Agreement is that it links adaptation needs with the level of mitigation (Article 9.4) and urges Parties to make finance flows consistent with low-carbon climate resilient development (Article 2.1c). However, Article 8 on loss and damage does not bear any liability and compensation claims.

The post-Paris developments, however, do not paint a bright picture. In 2016, just before the start of COP22 in Marrakech, developed countries floated a new Roadmap on climate finance. However, the Roadmap lacked clarity on core issues, including additionality and predictability (Roberts and Weikmans 2016). Intensive negotiations that year failed to produce an agreed framework on long-term finance. This ultimately was salvaged by the Moroccan COP Presidency, adopting an innocuous and anodyne text, just urging the developed countries to "scale up" the pledged mobilization of US\$100 billion a year by 2020 .

The Paris outcome was also not encouraging in the two years that followed. The most anticipated negotiations were COP24 in Katowice in 2018. During these negotiations, the COP adopted a Rulebook, which requires Parties to report on support provided and mobilized through public interventions (Annex of Decision 18/CMA.1, para. 118-129). Parties are further required to provide more information than before on several key aspects of their accounting methodologies. However, the new accounting modalities for financial resources provided and mobilized still leave considerable discretion to Parties (van Asselt et al. 2018). The language is relatively permissive, which allows countries to report the full value of loans, rather than their "grant equivalent" share (Annex of Decision 18/CMA.1, para. 118-129). In the absence of an agreed understanding of what climate finance is, developed countries will continue to have wiggle room for creative accounting.

The persistent issue of double or even triple counting of the same money provided through the UNFCCC and non-UNFCCC delivery channels has not been resolved. The developed countries have been allowed to report on their own about how they count "new and additional" climate finance. This subjective fixing of accounting methodologies by finance providers hardly allows any comparability. An additional prick is the extreme fragmentation of climate finance delivery with the total number of public and private channels currently ranging from 99 to over 500, including over 22 multilateral climate finance Funds (NDC Partnership 2018; OECD 2015). There are too many overlaps involving huge transaction costs, which generate frustrations both for contributors who are duplicating efforts and recipients who have mountains of tedious paperwork to file in order to access these Funds (Robinson and Dornan 2017; Robinson and Gilfillan 2017). This plainly warrants a "thinning out" of climate finance agencies. One positive decision at COP24, however, was for the organizing of a workshop before COP25 in Santiago de Chile on the "effectiveness" of climate finance on the ground.

Just weeks before COP24, the OECD published a report on climate finance, which showed that their Members had reported providing US\$56.7 billion in climate finance to developing countries in 2017 (OECD 2018a). Such figures, however, have been met with great skepticism, given over-reporting and double-counting in earlier periods (see Weikmans and Roberts 2018). Overall, the large gap between the amount of finance that is claimed to be delivered as new and additional and the actual receipt of funds shows no sign of being bridged.

Another interesting dimension is that, though grants account for over a third of bilateral climate finance, they are a measly $10 \%$ of total multilateral funding (OECD 2018a, p. 5). The most vulnerable countries have persistently demanded adaptation funding in the form of grants 
to enhance their adaptive capacity and avoid greater indebtedness. Also, adaptation finance remains at one-fifth of total climate finance, though the often-repeated pledge has been to maintain a "balance" between mitigation and adaptation.

Amidst the clouds shrouding the skies of climate finance, it was announced in 2018 that the Adaptation Fund would be capitalized to the tune of US\$129 million; and so too would the GCF - Germany pledged US\$1.7 billion with France, Japan, Norway, Sweden, the United Kingdom, and others also making pledges. It is expected that the European Union may lead to fill the gap left by the USA, which had declared its withdrawal from the GCF as well as the Paris Agreement. Developed countries appear more interested in supporting capacity building for transparency in developing countries, than ensuring their own transparency of climate finance support. This is evident in the obligatory nature of funding for the former (Article 13 of the Paris Agreement), rather than for generic capacity building in the Global South (Article 11).

\subsection{Who should get adaptation finance?}

The problems of allocation remain much as they were in the previous period after the Paris negotiations. The Adaptation Fund, now serving the Paris Agreement, is likely to get richer, compared with the Funds explicitly designed to support the needs of the most vulnerable countries, including the LDCF and the SCCF. This was the first time that the Adaptation Fund garnered an amount higher than expected. Though the Adaptation Fund has prioritized the particularly vulnerable countries since its operationalization about a decade ago, the Africa Group at COP24 failed to be recognized by Parties as a priority constituency for climate action support.

\subsection{Governance of financial mechanisms-the GCF and the Adaptation Fund}

The period after Paris has also resulted in ongoing low-level struggles over the governance of climate finance. As mentioned before, only a small proportion of climate finance is channeled through the UNFCCC architecture, including the GCF, which began its journey with an initial capitalization of US $\$ 10.3$ billion (initially planned to be spent over three to four years). Many developing country observers believed it would be handling the full US\$100 billion a year commitment, but this is not the case. Over $60 \%$ of the US $\$ 10.3$ billion has been deposited in the GCF's coffers, and over half of it has been delivered to around 75 projects. But there are several tensions. These include establishing criteria-based rationale for climate-related project proposals, enhancing access to the Fund, ensuring a level playing field for all Parties, making decisions according to consensus, and the reported politicization of the project approval process. Further, the USA had announced it would not deliver US\$2 billion of the US\$3 billion it had pledged.

\section{Conclusion}

This article sought to define the range of issues to be considered when evaluating the relationship between adaptation finance and climate justice; it also assessed what we know and do not know a quarter century into the process. How, finally, can a justice frame and criteria be deployed to influence behavior by big, wealthy nations and by international agencies and banks?

In the initial period from the drafting to the adoption of the UNFCCC in 1992, relatively abstract principles were translated into concrete institutional forms. The pivotal Copenhagen 
and Paris negotiations in 2009 and 2015, respectively, both saw adaptation finance as a core and contentious issue, especially from the perspective of particularly vulnerable countries. While Copenhagen saw some progress toward concrete commitments and institutional developments, the Paris Agreement, six years later, offered few gains in terms of justice. While the world has continued to warm, and climate impacts and costs increase exponentially, even the commitments made in Copenhagen show little promise of being honored. Ambiguity in key areas of climate finance governance related to distributive, procedural, recognition, and compensatory forms of justice still plague the UNFCCC regime. Moreover, where there is ambiguity, the history discussed here shows that powerful countries often creatively interpret expectations according to their own self-interests.

Looking at the broad sweep of whether "the arc of history" has bent towards climate justice (Roberts 2018, p. 163), we conclude that for adaptation finance, the answer is no. Several criteria laid out in our initial fundamental principles of climate adaptation justice have never been met, and in some ways, the international system seems farther than ever from meeting them, and less likely now to form a unified voice about this crucial issue. On the other hand, developing countries had to agree to forego any option of claiming compensation under the agenda of loss and damage.

The contemporary period of governance, rooted in neoliberal principles, presents distinct challenges for achieving justice related to adaptation finance. Specifically, the post-Paris context is characterized by a neglect of distributive justice as a guiding principle in favor of libertarian justice ideals, which emphasize the rational pursuit of self-interest, the deemphasizing of public responsibility in favor of a focus on the market and private sector to solve collective problems, the sidelining of the "polluter pays" principle and command-andcontrol forms of governance in favor of a focus on transparency without robust systems of accountability (Ciplet et al. 2018), and exclusive decision-making processes in which core decisions are increasingly made bilaterally between powerful States outside of the consensusbased process of the UNFCCC (Ciplet and Roberts 2017). As such, the principles governing adaptation finance have largely reflected neoliberal justice. This has included a focus on voluntary action, a growing emphasis on leveraging private finance and market-based strategies, and a refusal by wealthy States to define commitments in relation to responsibility, developing country needs, liability, or historical debt.

We would argue that justice on climate finance is a bedrock issue to ambitious agreements on addressing this existential issue, and sadly, our review of the $25+$ years of negotiations and fund provision does not paint a rosy picture. We, therefore, call for a turn towards centering finance justice issues of adequate and fair distribution of funds, of attention to governance, efficiency and accountability, and renewed dedication to collaboration across the North-South divide.

Open Access This article is distributed under the terms of the Creative Commons Attribution 4.0 International License (http://creativecommons.org/licenses/by/4.0/), which permits unrestricted use, distribution, and reproduction in any medium, provided you give appropriate credit to the original author(s) and the source, provide a link to the Creative Commons license, and indicate if changes were made.

\section{References}

AOSIS (2009) Proposal by the Alliance of Small Island States (AOSIS) for the survival of the Kyoto Protocol and a Copenhagen Protocol to enhance the implementation of the United Nations Framework Convention on Climate Change. http://www.washingtonpost.com/wp-srv/photo/homepage/AOSIS1.pdf?noredirect=on. Cited June 20, 2019. 
Baer P, Athanasiou T, Kartha S, et al. (2009) The greenhouse development rights framework: the right to development in a climate constrained world. http:/gdrights.org/wp-content/uploads/2009/01/ thegdrsframework.pdf. Cited January 30, 2019.

Betzold C, Weiler F (2017) Allocation of aid for adaptation to climate change: do vulnerable countries receive more support? Int Environ Agreements: Polit, Law Econ 17:17-36. https://doi.org/10.1007/s10784-0169343-8

Buchner B, Stadelmann M, Wilkinson J, et al. (2014) The global landscape of climate finance 2014. http:// climatepolicyinitiative.org/wp-content/uploads/2014/11/The-Global-Landscape-of-Climate-Finance2014.pdf. Cited March 19, 2015.

Caney S (2005) Cosmopolitan justice, responsibility, and global climate change. Leiden J Int Law 18:747-775. https://doi.org/10.1017/S0922156505002992

CAN International (2007) Climate negotiations: NGO Newsletter. ECO, 7th edn. Climate Action Network, Bali, $\mathrm{p} 4$

CAN International (2010) Vulnerability is not a beauty contest. http://www.climatenetwork. org/blog/vulnerability-not-beauty-contest. Cited March 9, 2013.

Caravani A, Nakhooda S, Watson C (2012) The global climate finance architecture. http://www.odi.org/sites/ odi.org.uk/files/odi-assets/publications-opinion-files/7908.pdf. Cited November 7, 2014.

Carty T, Comte AL (2018) Climate finance shadow report 2018: assessing progress towards the $\$ 100$ billion commitment. https://d1tn3vj7xz9fdh.cloudfront.net/s3fs-public/file_attachments/bp-climate-finance-shadow-report-030518-en.pdf. Cited January 30, 2019.

Ciplet D, Roberts JT (2017) Climate change and the transition to neoliberal environmental governance. Glob Environ Chang 46:148-156. https://doi.org/10.1016/j.gloenvcha.2017.09.003

Ciplet D, Roberts JT, Khan M (2013) The politics of international climate adaptation funding: justice and divisions in the greenhouse. Global Environ Politics 13:49-68. https://doi.org/10.1162/GLEP_a_00153

Ciplet D, Roberts JT, Khan MR (2015) Power in a warming world: the new global politics of climate change and the remaking of environmental inequality. MIT Press, Cambridge

Ciplet D, Adams KM, Weikmans R et al (2018) The transformative capability of transparency in global environmental governance. Global Environ Politics 18:130-150. https://doi.org/10.1162/glep_a_00472

CorpWatch (2002) Bali principles of climate justice. https://corpwatch.org/article/bali-principles-climate-justice. Cited June 20, 2019.

Dellink R, den Elzen M, Aiking $\mathrm{H}$ et al (2009) Sharing the burden of financing adaptation to climate change. Glob Environ Chang 19:411-421. https://doi.org/10.1016/j.gloenvcha.2009.07.009

Fraser N (1998) Social justice in the age of identity politics: redistribution, recognition, participation. https:// www.ssoar.info/ssoar/bitstream/handle/document/12624/ssoar-1998-fraser-social_justice_in_the_ age.pdf?sequence=1. Cited January 30, 2019.

Fraser N, Honneth A (2004) Redistribution or recognition? A political-philosophical exchange. Verso, New York

Füssel H-M (2010) Review and quantitative analysis of indices of climate change exposure, adaptive capacity, sensitivity, and impacts. http://hdl.handle.net/10986/9193. Cited June 22, 2019.

G77 and China (2000) Havana programme of action. http://www.g77.org/summit/ProgrammeofAction G77Summit.htm. Cited June 14, 2019.

GEF (2010) System for transparent allocation of resources (STAR). https:/www.thegef.org/publications/systemtransparent-allocation-resources-star. Cited January 31, 2019.

Gewirtzman J, Natson S, Richards J-A et al (2018) Financing loss and damage: reviewing options under the Warsaw International Mechanism. Clim Pol 18:1076-1086. https://doi.org/10.1080/14693062.2018.1450724

Goodin RE (1989) Theories of compensation. Oxf J Leg Stud 9:56-75 http://www.jstor.org/stable/764337

Government of Bolivia (2009a) Bolivia proposal 13 Dec 2009: integration into paragraph 23. https://unfccc.int/ files/kyoto protocol/application/pdf/bolivia141209.pdf. Cited June 14, 2019.

Government of Bolivia (2009b) Submission by Republic of Bolivia to the ad hoc working group on long-term cooperative action under the [UN Framework Convention on Climate Change] (AWG-LCA). http:// boliviarising.blogspot.com/2009/04/bolivia-rich-countries-must-pay-their.html. Cited June 14, 2019.

Government of India (2015) Climate change finance, analysis of a recent OECD report: some credible facts needed. http://pibphoto.nic.in/documents/rlink/2015/nov/p2015112901.pdf. Cited January 30, 2019.

Government of Tuvalu (2007) International blueprint on adaptation. https:/unfccc.int/resource/docs/2007/cop13/ eng/misc02.pdf. Cited June 15, 2019.

Grasso M (2010) Justice in funding adaptation under the international climate change regime. Springer, Dordrecht

Hobson B (ed) (2003) Recognition struggles and social movements: contested identities, agency and power. Cambridge University Press, Cambridge

Ikeme J (2003) Climate change daaptational deficiencies in developing countries: the case of Sub-Saharan Africa. Mitig Adapt Strateg Glob Chang 8:29-52. https://doi.org/10.1023/A:1025838610473 
Inuit Circumpolar Council (2009) Report of the indigenous peoples' global summit on climate changeinuit circumpolar council. http://webcache.googleusercontent.com/search?q=cache:Jyq51wjRNiQJ:www.un.org/ ga/president/63/letters/globalsummitoncc.pdf+\&cd=1\&hl=en\&ct=clnk\&gl=us. Cited June 20, 2019.

Jagers SC, Duus-Otterström G (2008) Dual climate change responsibility: on moral divergences between mitigation and adaptation. Environmental Politics 17:576-591. https://doi.org/10.1080/09644010802193443

Khan MR (2014) Toward a binding climate change adaptation regime. Routledge, London

Khan MR (2015) Polluter-pays-principle: the cardinal instrument for addressing climate change. Laws 4:638653. https://doi.org/10.3390/laws4030638

Khan MR, Roberts JT (2013) Towards a binding adaptation regime: three levers and two instruments. In: Moser SC, Boykoff MT (eds) Successful adaptation to climate change: linking science and policy in a rapidly changing world. Routledge, Oxon, pp 132-148

Khan MA, Shamsuddoha M, Helal AA et al (2013) Climate change mitigation approaches in Bangladesh. J Sustain Dev 6:59. https://doi.org/10.5539/jsd.v6n7p59

Khastagir N (2002) The human face of climate change. https://www.globalpolicy.org/component/content/article/ 211/44309.html. Cited June 2, 2019.

Klein RJT (2009) Identifying countries that are particularly vulnerable to the adverse effects of climate change: an academic or a political challenge? Carbon Climate Law Rev 3:284-291

Klinsky S, Dowlatabadi H (2009) Conceptualizations of justice in climate policy. Clim Pol 9:88-108. https://doi. org/10.3763/cpol.2008.0583b

Kono DY, Montinola GR (2019) Foreign aid and climate change policy: what can('t) the data tell us? Polit Govern 7:68-92. https://doi.org/10.17645/pag.v7i2.1840

Martinez-Alier J (2002) The environmentalism of the poor: a study of ecological conflicts and valuation. Edward Elgar, Cheltenham and Northampton

Nakhooda S, Fransen T, Kuramochi T, et al. (2013) Mobilising international climate finance: lessons from the fast-start finance period. https://www.odi.org/sites/odi.org.uk/files/odi-assets/publications-opinion-files/ 8686.pdf. Cited August 5, 2016.

Narain U, Margulis S, Essam T (2011) Estimating costs of adaptation to climate change. Clim Pol 11:1001-1019. https://doi.org/10.1080/14693062.2011.582387

NDC Partnership (2018) Climate funds update. http://ndcpartnership.org/content/climate-funds-update. Cited January $30,2019$.

Nizam I (2009) Environment prosecution: we need implementable laws - environment minister. http:// www.island.lk/2009/07/06/business9.html. Cited June 20, 2019.

OECD (2015) Climate fund inventory: a report to the G20 climate finance study group. https://bit.ly/2TLayaY. Cited January 28, 2019.

OECD, CPI (2015) Climate finance in 2013-14 and the USD 100 billion goal. https://bit.ly/2Ob45Qs. Cited January $30,2019$.

OECD (2018a) Climate finance from developed to developing countries: public flows in 2013-17. http:// www.oecd.org/environment/cc/Climate-finance-from-developed-to-developing-countries-Public-flows-in2013-17.pdf. Cited January 30, 2019.

OECD (2018b) Official development assistance (ODA). http://www.oecd.org/dac/stats/What-is-ODA.pdf. Cited February 1, 2019.

Okereke C (2008) Global justice and neoliberal environmental governance: ethics, sustainable development and international cooperation. Routledge, Oxon

Ourbak T, Magnan AK (2017) The Paris agreement and climate change negotiations: small islands, big players. Reg Environ Chang:1-7. https://doi.org/10.1007/s10113-017-1247-9

Paavola J, Adger WN (2006) Fair adaptation to climate change. Ecol Econ 56:594-609. https://doi.org/10.1016/j. ecolecon.2005.03.015

Page EA (2008) Distributing the burdens of climate change. Environmental Politics 17:556-575. https://doi. org $/ 10.1080 / 09644010802193419$

Pan-African Climate Justice Alliance (2009) Call for climate justice - repay the climate debt: declaration of African civil society organisations (CSOs) to the 3rd session of AMCEN on climate change. https://pheethiopia.org/admin/uploads/attachment-108-Call_for_climate_justice_revised_versionf_-_26_May_9am\%5B1\%5D.pdf. Cited June 20, 2019.

Rabble News (2009) The declaration of Cumaná: capitalism 'threatens life on the planet'. http://rabble.ca/news/ 2009/04/declaration-cuman\%C3\%A1-capitalism-threatens-life-planet. Cited June 20, 2019.

Raman M, Lin LL (2009) Sign-on letter calling for repayment of climate debt. http:// www.ourworldisnotforsale.org/en/action/sign-letter-calling-repayment-climate-debt/. Cited June 16, 2019.

Rawls J (1971) A theory of justice. Belknap Press of Harvard University Press. Massachusetts, Cambridge

Richards J-A, Boom K (2014) Carbon majors funding loss and damage. https://ke.boell.org/sites/default/files/ carbon_majors_funding_loss_and_damage_kommentierbar.pdf. Cited January 25, 2019. 
Roberts JT (2018) Does the arc of history bend towards climate justice? Towards anagenda for engaged research. In: Dauvergne P, Alger J (eds) A research agenda for global environmental politics. Edward Elgar Publishing, Cheltenham, pp 163-176

Roberts JT, Parks B (2006) A climate of injustice: global inequality, North-South politics, and climate policy. MIT Press, Boston

Roberts JT, Parks BC (2009) Ecologically unequal exchange, ecological debt, and climate justice: the history and implications of three related ideas for a new social movement. Int J Comp Sociol 50:385-409. https:/doi. org/10.1177/0020715209105147

Roberts JT, Weikmans R (2016) Roadmap to Where? Is the '\$100 billion by 2020' pledge from Copenhagen still realistic? https://wwwbrookingsedu/blog/planetpolicy/2016/10/20/roadmap-to-where-is-the-100-billion-by2020-pledge-from-copenhagen-still-realistic/ Cited June 22, 2019.

Roberts JT, Weikmans R (2017) Postface: fragmentation, failing trust and enduring tensions over what counts as climate finance. Int Environ Agreements: Polit, Law Econ 17:129-137. https://doi.org/10.1007/s10784-0169347-4

Robinson S-a (2018a) Adapting to climate change at the national level in Caribbean small island developing states. Isl Stud J 13:79-100. https://doi.org/10.24043/isj.59

Robinson S-a (2018b) Climate change adaptation in small island developing states: insights and lessons from a meta-paradigmatic study. Environ Sci Pol 85:172-181. https://doi.org/10.1016/j.envsci.2018.03.030

Robinson S-a, Dornan M (2017) International financing for climate change adaptation in small island developing states. Reg Environ Chang 17:1103-1115. https://doi.org/10.1007/s10113-016-1085-1

Robinson, S-a, Gilfillan, D (2017) Regional organisations and climate change adaptation in small island developing states. Reg Environ Chang 17(4):989-1004. https://doi.org/10.1007/s10113-016-0991-6

Schalatek L, Bird N (2015) The principles and criteria of public climate finance: a normative framework. https:// bit.ly/2HDDHyo. Cited January 25, 2019.

Shue H (1992) The unavoidability of justice. In: Hurrell A, Kingsbury B (eds) The international politics of the environment: actors, interests, and institutions. Clarendon Press, Oxford, pp 373-397

Simms A, Meyer A, Robbins N (1999) Who owes who?: Climate change, debt, equity and survival. http:// www.gci.org.uk/Documents/Who_Owes_Who_a.pdf. Cited June 2, 2019.

Third World Network (2009) Bonn news updates and climate briefings (June 2009). https://www.twn.my/title2/ books/bonn.news.climate.briefings4.htm. Cited June 16, 2019.

Third World Network (2010) Copenhagen accord fails to deliver, say some SIDS and LDC leaders. https:// www.twn.my/title2/climate/news/cancun01/cancun.news.18.pdf. Cited June 16, 2019.

Thwaites J (2018) US 2018 budget and climate finance: it's bad, but not as bad as you might think. https:// www.wri.org/blog/2018/03/us-2018-budget-and-climate-finance-its-bad-not-bad-you-might-think. Cited January 20, 2019.

UNEP (2016) Adaptation finance gap report. https://bit.ly/2G1cIgr. Cited July 6, 2016.

United States Government (2018) Consolidated appropriations Act, 2018. https://www.govinfo.gov/content/pkg/ CPRT-115HPRT29374/pdf/CPRT-115HPRT29374.pdf. Cited January 25, 2019.

van Asselt H, Weikmans R, Roberts JT (2018) Pocket guide to transparency under the UNFCCC: 2019 update. https://ecbi.org/sites/default/files/Final-Transparency_2019_0.pdf. Cited June 23, 2019.

Vanderheiden S (2011) Globalizing responsibility for climate change. Ethics Int Aff 25:65-84. https://oi. org/10.1017/S089267941000002X

Vanhala L, Hestbaek C (2016) Framing climate change loss and damage in UNFCCC negotiations. Global Environ Politics 16. https://doi.org/10.1162/GLEP_a_00379

Weikmans R, Roberts JT (2018) It's déjà vu all over again: climate finance at COP24. https:// www.brookings.edu/blog/planetpolicy/2018/12/06/its-deja-vu-all-over-again-climate-finance-at-cop24/. Cited January 30, 2019.

Weikmans R, Roberts JT (2019) The international climate finance accounting muddle: is there hope on the horizon? Clim Dev 11:97-111. https://doi.org/10.1080/17565529.2017.1410087

Weikmans R, Roberts JT, Baum J et al (2017) Assessing the credibility of how climate adaptation aid projects are categorised. Dev Pract 27:458-471. https://doi.org/10.1080/09614524.2017.1307325

Young IM (1990) Justice and the politics of difference. Princeton University Press, Princeton

Publisher's note Springer Nature remains neutral with regard to jurisdictional claims in published maps and institutional affiliations. 


\section{Affiliations}

Mizan Khan ${ }^{1} \cdot$ Stacy-ann Robinson ${ }^{2} \cdot$ Romain Weikmans $^{3} \cdot$ David Ciplet $^{4} \cdot$ J. Timmons $^{-}$ Roberts $^{5}$

Mizan Khan

mizan.khan@icccad.net

Romain Weikmans

romain.weikmans@ulb.be

David Ciplet

david.ciplet@ colorado.edu

J. Timmons Roberts

timmons@brown.edu

1 LDC Universities Consortium on Climate Change (LUCCC), International Centre for Climate Change and Development (ICCCAD), Dhaka, Bangladesh

2 Environmental Studies Program, Colby College, Waterville, ME 04901, USA

3 Institute for Environmental Management and Land Use Planning, Université Libre de Bruxelles, Brussels, Belgium

4 Department of Environmental Studies, University of Colorado-Boulder, Boulder, CO 80303, USA

5 Institute at Brown for Environment and Society, Brown University, Providence, RI 02912, USA 